\title{
APRESENTAÇÃO
}

\section{OUTRO ENFOQUE A DESBRAVAR: LETRAMENTO CIENTÍFICO}

O crescimento dos estudos do letramento no cenário acadêmico brasileiro é indiscutível, săo diversos os enfoques por eles assumidos, alguns tematizados nesta apresentaçấo. Na década de 90 , com enfoques pedagógicos, foram expressivas as pesquisas desenvolvidas no contraponto entre os fenômenos da alfabetizaçáo e do letramento (cf. ROJO, 1998; SOARES, 1998). Afinal, esse último termo passou a ser utilizado para denominar práticas sociais mais amplas de uso da escrita, as quais eram acessadas com dificuldade por crianças familiarizadas com atividades escolares. Em outras palavras, a entăo denominada abordagem do letramento surgiu na esperança de complementaçâo das práticas de alfabetizaçâo, propostas para propiciar o conhecimento do sistema alfabético e ortográfico da língua portuguesa às crianças, contribuindo indiretamente para as demandas de leitura e escrita em espaços nâo escolares.

Enfoques nāo pedagógicos também foram desenvolvidos, a exemplo das inúmeras investigaçōes sobre o impacto da escrita em comunidades pouco ou năo escolarizadas, alcançando especialmente adultos como colaboradores ou participantes das pesquisas (cf. KLEIMAN, 1995; SIGNORINI, 1998; TFOUNI, 1994). Essas pesquisas foram motivadas por situaçôes interativas conflituosas, provocadas por relaçôes sociais assimétricas instauradas pela desigualdade de acesso a bens culturais socialmente valorizados pela comunidade letrada (cf. RAMA, 2015), a exemplo dos usos de variedades linguísticas desprestigiadas por cidadâos que passam a ocupar posiçôes ou lugares valorizados e para muitas pessoas inesperados conforme convençôes seletivas.

Considerando o marco temporal do início do século XXI, podemos destacar o letramento do professor e o letramento acadêmico como enfoques originários das vertentes pedagógicas das pesquisas realizadas. Nos primeiros estudos, foram identificadas práticas de leitura e escrita familiares e compartilhadas por professoras em domínios escolares ou nâo, resultando na valorizaçâo e discernimento de histórias de vida dessas profissionais, bem como na proposiçâo ou encaminhamento de práticas pedagógicas diferenciadas para garantir uma formaçăo inicial e continuada mais sustentável. Foram geradas ainda contribuiçōes para o exercício profissional mediado pela escrita, ou seja, envolvendo usos da escrita no próprio local de trabalho (cf. GUEDES-PINTO, 2002; KLEIMAN; ASSIS, 2016; OLIVEIRA; KLEIMAN, 2008; SILVA, 2012).

Os estudos do letramento acadêmico se desenvolveram em paralelo aos do letramento do professor. Em algumas situaçóes, năo conseguimos delimitar alguma fronteira entre os referidos enfoques, a exemplo de algumas pesquisas reunidas por Fuza e Silva (2017) e de Silva (2014). No contexto brasileiro, o letramento acadêmico compreende especialmente os estudos sobre o registro escrito materializado em diferentes gêneros do domínio universitário, abrangendo ainda as práticas de ensino de escrita no referido contexto institucional (cf. FIAD, 2015). 
Como prolongamento das vertentes teóricas sintetizadas nos parágrafos anteriores, surge o letramento científico, temática deste dossiê com dez artigos de autores que, assumindo algumas particularidades, desbravam um enfoque diferenciado dos estudos do letramento. Em sua maioria, săo pesquisas que se situam na Linguística Aplicada e dialogam diretamente com trabalhos desenvolvidos no âmbito do Ensino de Ciências e da Educaçâo, os quais têm o contraponto das abordagens da alfabetizaçâo e do letramento em suas bases, embora o enfoque sobre a escrita nem sempre esteja no centro das propostas pedagógicas.

Sem antecipar as contribuiçōes pontuais dos textos reunidos neste número especial da Revista Raído, destacamos que a abordagem do letramento científico possibilita situar algumas práticas de pesquisa como estratégias pedagógicas contextualizadoras do trabalho com diferentes objetos de ensino em disciplinas escolares. Os artigos apresentam ainda diferentes olhares sobre alguns impactos provocados por diferentes práticas científicas mediadas pela escrita no contexto escolar e universitário.

Finalizamos esta apresentaçâo agradecendo aos autores que colaboraram com seus artigos para compor este número temático inaugural dos estudos do letramento científico. Agradecemos ainda aos editores da Revista Raído pelo espaço disponibilizado para compartilhar este trabalho do grupo de pesquisa Práticas de Linguagens - PLES (UFT/CNPq). Aos leitores, desejamos uma leitura produtiva

\section{REFERÊNCIAS}

FIAD, Raquel S. Algumas consideraçôes sobre os letramentos acadêmicos no contexto brasileiro. Pensares em Revista. Rio de Janeiro: UERJ, n. 6, p. 23-34, 2015.

FUZA, Ângela F.; SILVA, Wagner R. Escrita na universidade. Revista Raído. Dourados: UFGD, v. 11, n. 27, 2, p. 9-10. 2017.

GUEDES-PINTO, Ana L. Rememorando trajetórias da professora-alfabetizadora: a leitura como prática constitutiva de sua identidade e formaçăo profissional. Campinas: Mercado de Letras, 2002.

KLEIMAN, Angela (Org.). Os significados do letramento. Campinas: Mercado de Letras, 1995.

KLEIMAN, Angela; ASSIS, Juliana Alves (Orgs.). Significados e ressignificaçóes do letramento: desdobramentos de uma perspectiva sociocultural sobre a escrita. Campinas: Mercado de Letras.

OLIVEIRA, Maria do S.; KLEIMAN, Angela B. (Orgs.). Letramentos múltiplos: agentes, práticas, representaçóes. Natal: EdUFRN, 2008.

RAMA, Ángel. A cidade das letras. Săo Paulo: Boitempo, 2015.

RIBEIRO, Vera Masagăo (Org.). Letramento no Brasil. Săo Paulo: Global Editora, 2003.

ROJO, Roxane (Org.). Alfabetizaçáo e letramento: perspectivas linguísticas. Campinas: Mercado de Letras, 1998. 
SIGNORINI, Inês (Org.). Língua(gem) e identidade: elementos para uma discussăo no campo aplicado. Campinas: Mercado de Letras, 1998.

SILVA, Wagner R. Reflexáo pela escrita no estágio supervisionado da licenciatura: pesquisa em Linguística Aplicada. Campinas: Pontes, 2014.

. (Org.). Letramento do professor em formaçâo inicial: interdisciplinaridade no estágio supervisionado. Campinas: Pontes Editores, 2012.

SOARES, Magda. Letramento: um tema em três gêneros. Belo Horizonte: Autêntica, 1998.

TFOUNI, Leda Verdiani. Letramento e alfabetizaçâo. Săo Paulo: Editora Cortez, 1995.

Wagner Rodrigues Silva - UFT/CNPq

Palmas (TO), 02 de outubro de 2018. 